\title{
Evaluation of free radical scavenging and pancreatic lipase inhibitory effects of Aquilaria agallocha extracts
}

\author{
Ha Yeong Lee ${ }^{1}$, In-Chul Lee ${ }^{2}$, Jae Hoon Kwak ${ }^{3}$, Tae Hoon Kim ${ }^{4 *}$ \\ ${ }^{1}$ Institute for Korea Traditional Medical Industry, Gyeongsan 712-260, Korea \\ ${ }^{2}$ Department of Cosmetic Science and Technology, Seowon University, Cheongju 361-742, Korea \\ ${ }^{3}$ Faculty of Biotechnology Convergence, Daegu Haany University, Gyeongsan 712-715, Korea \\ ${ }^{4}$ Department of Food Science and Biotechnology, Daegu University, Gyeongsan 712-714, Korea
}

\section{침향 추출물의 라디칼 및 췌장 지방분해 효소저해 활성 평가}

\author{
이하영 ${ }^{1} \cdot$ 이인철 $^{2} \cdot$ 곽재훈 $^{3} \cdot$ 김태훈 ${ }^{4 *}$ \\ ${ }^{1}$ 한국한방산업진흥원, ${ }^{2}$ 서원대학교 화장품과학과, ${ }^{3}$ 대구한의대학교 바이오산업융합학부, \\ ${ }^{4}$ 대구대학교 식품공학과
}

\begin{abstract}
In a continuing screening of selected medicinal plants native to South Korea, the antioxidant and pancreatic lipase inhibitory activities of an aqueous methanolic extract from the heartwood of Aquilaria agallocha were investigated. Eighty percent of the methanolic extract of $A$. agallocha was further divided into $\mathrm{CH}_{2} \mathrm{Cl}_{2}$, EtOAc and $n$-BuOH in order to yield four solvent-soluble portions, namely $\mathrm{CH}_{2} \mathrm{Cl}_{2}$-soluble, EtOAc-soluble, $n$-BuOH-soluble and $\mathrm{H}_{2} \mathrm{O}$ residue. The antioxidant properties were evaluated by employing radical scavenging assays using 1,1-diphenyl-2-picrylhydrazyl (DPPH) and 2,2'-azino-bis (3-ethylbenzothiazoline-6-sulphonic acid) (ABTS ${ }^{+}$) radicals, while the anti-obesity efficacy of $A$. agallocha extracts and solvent-soluble portions were tested by porcine pancreatic lipase assay. All tested samples showed dose-dependent radical scavenging and pancreatic lipase inhibitory activities. Among the tested extracts and solvent-soluble portions, the $\mathrm{CH}_{2} \mathbf{C l}_{2}$-soluble portion showed much higher radical scavenging activity and pancreatic lipase inhibitory properties when compared with other solvent-soluble portions. This result suggested that there was a significant relationship between the total phenolic content and biological efficacies, and $A$. agallocha extract might be considered as a new potential source of natural antioxidants and as a pancreatic lipase inhibitory source. A more systematic investigation of this biomass will be performed for further investigation of activity against antioxidative and anti-obesity effects.
\end{abstract}

Key words : Aquilaria agallocha, antioxidant activity, DPPH, $\mathrm{ABTS}^{+}$, pancreatic lipase inhibition

\section{서 론}

생체는 물질의 대사와 에너지 생산을 필수적으로 산소를 이용하고 있으며, 이러한 산소로 부터의 산화적 스트레스 는 인체 내에의 산화촉진물질(prooxidant)과 산화억제물질

*Corresponding author. E-mail : skyey7@daegu.ac.kr Phone : 82-53-850-6533, Fax : 82-53-850-6539

Received 23 April 2015; Revised 27 May 2015; Accepted 28 May 2015.

Copyright (c) The Korean Society of Food Preservation. All rights reserved. (antioxidant)이 균형이 무너진 상태로 상태가 지속 되면 활 성산소가 급격히 증가해 인체에 악영향을 끼친다. $(1,2)$ 활성산소는 반응성이 강한 유해한 성분으로서 생체의 성분 과 빠르게 반응하여 산화시키며, 활성산소의 과도한 발생 은 체내 고분자들을 공격하여 세포와 조직에 비가역적인 손상을 일으켜 각종질병과 노화 등을 촉진하게 된다 $(3,4)$. 따라서 항산화 물질은 생체의 산화를 방지하는 물질로 체내 에서 활성산소종(reactive oxygen species)과 free radical이 $\mathrm{DNA}$ 를 공격하거나, 지질을 산화시키기 전에 활성산소를 효과적으로 소거하여 노화방지, 성인병 예방 등의 기능을 한다 $(5,6)$. 활성산소종이 야기하는 손상을 억제하기 위한 
항산화활성물질로서 최근에 개발된 다양한 천연 항산화제 들과 함께 butylated hydroxy anisol(BHA) 및 butylated hydroxy toluene(BHT) 등의 합성 항산화제가 많이 사용되 어졌으며, 이들을 고용량으로 장기간 복용 시 독성을 유발 시킬 수 있으므로 사용을 제한을 권고하고 있다(7). 따라서, 이러한 합성 항산화제를 대체할 수 있는 우수한 소재의 개발이 요구되고 있으며, 최근에는 각종 천연소재 등에서 보다 안전하고 항산화 효과가 뛰어난 천연 항산화제를 개발 하기 위한 많은 연구가 활발하게 진행되고 있다(8).

비만은 섭취에너지와 소비에너지의 불균형에 의한 에너 지 대사이상으로 지방세포에 중성지방이 과도하게 축적된 상태이다(9). 최근 서구화된 식습관으로 인하여 비만인구 가 급격히 증가하고 있으며, 비만의 가장 큰 원인은 고열량 이나 고지방을 함유한 음식의 섭취 및 운동 부족으로 인한 과도한 체내지방 축적이지만, 이외에도 신경내분비 계통의 이상, 약물, 유전적 요인 및 생화학적 이상반응에 의해서도 유발되는 것으로 보고되어 있다(10). 비만은 외형상의 문제 외에도 고혈압 및 고지혈증, 제 2형 당뇨병, 고혈압, 심장질 환, 뇌졸중, 관절염, 동맥경화, 암, 대사증후군, 수면무호흡 증, 관절염, 요통 등의 만성질환과 밀접한 연관이 있음이 잘 알려져있다(11-13). 비만의 치료와 예방에 있어서 식이 요법을 동반한 운동이 가장 적절한 방법이나 최근에는 식욕 억제제, 지방흡수 억제제의 개발이 진행되고 있으며, 그중 에서도 triglyceride를 2-monoacylglycerol과 fatty acid로 분 해하는 key enzyme으로 작용하는 지방분해효소인 pancreatic lipase의 작용을 억제하는 방법이 주목을 받고 있다(14). 현재 항비만 의약품으로서 시판중인 lipstatin의 유도체인 tetrahydrolipstatin(orlistat)은 Streptomyces toxitricini로부터 유래된 대표적인 pancreatic lipase inhibitor로서 체내에 섭취 된 지방의 소화와 흡수를 억제해 섭취량의 약 $30 \%$ 를 그대 로 배설 시키나, 최근 위장장애, 과민증, 담즙분비장애, 지 용성 비타민 흡수억제 등의 부작용이 있는 것이 보고됨에 따라 보다 부작용이 적은 새로운 항비만 물질의 개발이 요구되고 있다(15-17). 최근, 천연소재로부터 pancreatic lipase 저해제 개발을 위한 연구가 활발하게 진행 되고 있으 며(18), 택사(Alisma orientale), 측백나무(Thuja orientalis), 배나무(Pyrus pyrifolia)등의 천연 식물로부터 지방분해 효 소를 효과적으로 억제하는 자생약용식물이 보고되었다 (19). 본 연구팀에서도 천연소재 유래의 항비만 소재개발의 일환으로 약용식물 및 생물전환기법을 적용하여 pancreatic lipase 저해제를 분리하여 그 효능에 대해 보고하였다 (20-22).

침향나무는 팥꽃나무과(Thymelaeaceae)에 속하는 방향 성 수지질의 상록성 교목으로 인도, 베트남, 라오스, 중국 등의 동남아시아 지역에 분포하며 국제적인 멸종위기종으 로 지정되어 있다. 또한 침향나무의 심재부분인 침향은 한 국, 중국, 일본 등에서는 예로부터 피부소양, 복통, 천식
등의 치료에 사용되어 왔으며 진정, 건위, 소화불량, 식욕부 진 등에 전통약재로 사용되고 있다(23). 최근의 연구에서 항알러지, 항균, 항산화 등의 효능이 보고되었으며, 주요성 분으로서는 sesquiterpene류, chromone 유도체, coumarinolignan 류 등의 존재가 알려져 있다(24-29).

본 연구에서는 약용식물로부터 항산화 및 pancreatic lipase 저해활성을 나타내는 천연소재를 탐색하고자 그 효 능을 평가하였으며, 그중에서 우수한 저해능을 나타낸 침 향의 $80 \% \mathrm{MeOH}$ 추출물 및 각 유기용매 가용부에 대하여 강한 라디칼 소거능 및 pancreatic lipase 저해능을 확인하였 기에 그 결과를 보고하고자 한다.

\section{재료 및 방법}

\section{재 료}

본 실험에 시료로 사용한 침향(Aquilaria agallocha)은 2010년 2월에 대구시 소재 약업사에서 구입하여 잘게 세절 한 다음 사용하였으며, 표본시료는 대구대학교의 식품공학 과 식품분석실험실에 보관하고 있다. 또한 1,1-diphenyl2-picrylhydrazyl(DPPH), 2,2'-azino-bis(3-ethylbenzothiazoline6-sulphonic acid)(ABTS), Folin-Ciocalteu's phenol 시약, porcine pancreatic lipase, (+)-catechin 등의 시약은 Sigma 사에서 구입하여 사용하였다. 추출용 유기용매류는 특급시 약을 사용하였고 흡광도 측정을 위한 spectrophotometer는 Tecan 사의 Infinite F200(Tecan Austria GmBH, Grödig, Austria)을 사용하였다.

\section{추출물의 제조 및 분획}

건조된 침향 $1.2 \mathrm{~kg}$ 을 잘게 부순 후 $80 \%$ methanol(MeOH) $8 \mathrm{~L}$ 로 3 일간 3 회 반복 추출 하였다. 얻어진 용액을 여과한 후, 감압 농축하여 $80 \% \mathrm{MeOH}$ 추출물 $185.3 \mathrm{~g}$ 을 얻었다. 얻어진 침향 추출물을 물에 현탁하여 유기 용매의 극성차를 이용하여 methylene chloride $\left(\mathrm{CH}_{2} \mathrm{Cl}_{2}\right)$, ethyl acetate(EtOAc), $n$-butanol $(n-\mathrm{BuOH})$ 로 순차적으로 3 회 분획하여 추출하였 다. 각 분획물을 감압 농축하여 건조 시킨 후 $\mathrm{CH}_{2} \mathrm{Cl}_{2}$ 가용부 $(55.9 \mathrm{~g}), \mathrm{EtOAc}$ 가용부 $(91.7 \mathrm{~g}), n-\mathrm{BuOH}$ 가용부 $(28.5 \mathrm{~g})$, $\mathrm{H}_{2} \mathrm{O}$ 가용부 $(3.4 \mathrm{~g})$ 를 각각 얻었으며 각 가용부를 대상으로 라디칼 소거능 및 지방분해효소 저해능을 평가하였다.

\section{$\mathrm{DPPH}$ 라디칼소거능 측정}

침향 $80 \% \mathrm{MeOH}$ 추출물 및 유기용매 가용부의 전자공여 능은 Blois 방법(30)을 변형하여 측정하였다. 각 시료용액에 $120 \mu \mathrm{L}$ 에 $0.45 \mathrm{mM}$ 의 1,1-diphenyl-2-picrylhydrazyl(DPPH) 용액 $60 \mu \mathrm{L}$ 를 넣고 교반 후 15 분간 방치한 다음 $517 \mathrm{~nm}$ 에서 흡광도를 측정하였다. 이때 양성대조군으로는 (+)-catechin 를 사용했으며 전자공여능은 시료용액의 첨가군과 무첨가 
군의 흡광도 차이를 백분율로 나타내었다.

\section{$\mathrm{ABTS}^{+}$라디칼 소거능 측정}

2,2'-Azinobis-3-ethylbenzothiazoline-6-sulfonic $\operatorname{acid(ABTS)~radical~ㅅㅗㄱㅓㄴㅡㅇㅇㅡㄴ~} \operatorname{Re}(31)$ 의 방법을 변형하여 다 음과 같이 측정하였다. $7 \mathrm{mM} \mathrm{ABTS(in} \mathrm{water)와} 2.4 \mathrm{mM}$ $\mathrm{K}_{2} \mathrm{O}_{8} \mathrm{~S}_{2}$ 를 동량을 혼합 후 실온, 암소에서 12 시간 방치하여 라디칼의 생성을 유도한 후 $734 \mathrm{~nm}$ 에서 흡광도 값이 0.6 0.7 정도가 되도록 희석하여 사용하였다. 희석한 $\mathrm{ABTS}^{+}$ 라디칼 용액 $100 \mu \mathrm{L}$ 와 생약 추출액 $100 \mu \mathrm{L}$ 을 혼합하여 실온에서 7분간 반응시킨 후 $734 \mathrm{~nm}$ 에서 흡광도를 측정하 였다. 이때 대조물질로는 (+)-catechin를 사용하였으며 결과 는 시료를 처리하지 않은 군에 대한 \%로 표시하였다.

\section{Pancreatic lipase 저해활성 측정}

Pancreatic lipase 저해활성 측정은 Kim 등이 행한 방법 (32)을 변형하여 실시하였다. Enzyme buffer(10 mM MOPS, $1 \mathrm{mM}$ EDTA, pH 6.8)에 porcine pancreatic lipase를 $0.5 \mathrm{~g} / 200$ $\mathrm{mL}$ 의 농도로 $4^{\circ} \mathrm{C}$ 에서 $4,000 \mathrm{rpm}$ 으로 원심 분리를 하여 상층액을 사용하여 $169 \mathrm{uL}$ Tis buffer $(100 \mathrm{mM}$ Tris- $\mathrm{HCl}$, $5 \mathrm{mM} \mathrm{CaCl}_{2}, \mathrm{pH}$ 7.0) 와 $6 \mathrm{uL}$ enzyme buffer를 혼합한다. 샘플은 distilled water로 용해하여 다양한 농도로 희석하여 사용하였다. Enzyme과 sample을 먼저 $37^{\circ} \mathrm{C}$ 에서 15 분 동안 shaking incubation 시킨 후 기질로 $10 \mathrm{mM}$ p-nitrophenyl butyrate (p-NPB)를 첨가 하여 $37^{\circ} \mathrm{C}$ 에서 30 분 동안 shaking incubation 시킨 후 $405 \mathrm{~nm}$ 에서 흡광도를 측정하였다. Pancreatic lipase 저해활성은 시료용액의 첨가군과 무첨가 군의 흡광도 감소율로 나타내었다.

\section{총 페놀 화합물 함량 평가}

총 페놀 화합물의 함량은 Folin-Denis 방법(33)에 따라 측정하였으며, 추출물 혹은 가용부 시료액 $50 \mu \mathrm{L}$ 와 Folin-Denis 시액 $50 \mu \mathrm{L}$ 을 넣고 3분 후, $0.7 \mathrm{M}$ 탄산나트륨
용액 $50 \mu \mathrm{L}$ 를 넣고 잘 혼합하여 실온에서 60 분 방치한 후, UV/VIS 분광광도계로 $730 \mathrm{~nm}$ 에서 흡광도를 측정하였 으며, 표준물질은 tannic acid를 이용하여 표준곡선을 작성 하여 양을 환산하였다.

\section{결과 및 고찰}

\section{$\mathrm{DPPH}$ 라디칼 소거활성}

항산화 물질의 가장 큰 특징적인 기작은 유리기와 반응 하는 것으로 유리기 소거 작용은 활성 라디칼에 전자를 공여하여 항산화 효과를 평가 하는 척도로 이용된다. DPPH 는 생체 내에 존재하는 라디칼은 아니지만 그 자체가 홀수 전자를 갖고 있는 수용성 물질로서 약 $517 \mathrm{~nm}$ 에서 강한 흡광도를 나타낸다. 항산화능이 있는 물질과 반응하게 되 면 전자를 내어 주면서 라디칼이 소멸되고 특유의 보라색이 없어지면서 안정한 형태로 돌아가면서 흡광도 값이 감소한 다(34). Fig. 2에서 나타낸 것처럼 침향 $80 \% \mathrm{MeOH}$ 추출물 및 각 유기용매 가용부에 대해서 라디칼 소거능을 평가한 결과, 침향 $80 \% \mathrm{MeOH}$ 추출물은 $26.9 \pm 4.5 \mu \mathrm{g} / \mathrm{mL}$ 의 비교적 강한 $\mathrm{IC}_{50}$ 값을 나타내었으며, 유기용매 가용부에 대해 같은 방법으로 활성을 평가한 결과, $\mathrm{CH}_{2} \mathrm{Cl}_{2}$ 가용부에서 $26.1 \pm 4.4$ $\mu \mathrm{g} / \mathrm{mL}, \mathrm{EtOAc}$ 가용부에서 $24.8 \pm 3.9 \mu \mathrm{g} / \mathrm{mL}$ 의 $\mathrm{IC}_{50}$ 값을 나타 내었다. 또한 $n-\mathrm{BuOH}$ 가용부 $\left(\mathrm{IC}_{50} ; 42.7 \pm 5.6 \mathrm{\mu g} / \mathrm{mL}\right), \mathrm{H}_{2} \mathrm{O}$ 가용부 $\left(\mathrm{IC}_{50} ; 186.8 \pm 7.1 \mathrm{\mu g} / \mathrm{mL}\right)$ 의 순으로 라디칼 소거 활성 을 나타내었으며 이러한 결과를 양성 대조군인 (+)-catechin 의 $\mathrm{IC}_{50}$ 값인 $5.9 \pm 0.4 \mu \mathrm{g} / \mathrm{mL}$ 의 라디칼 소거능과 비교 시 단일 물질이 아닌 $\mathrm{MeOH}$ 추출물 및 유기용매 분획임을 고려할 때 상대적으로 우수한 활성임을 시사하였다.

\section{$\mathrm{ABTS}^{+}$라디칼 소거능 측정}

$\mathrm{ABTS}^{+}$라디칼 소거활성은 $\operatorname{Re}(31)$ 의 방법을 변형하여 $\mathrm{ABTS}$ 의 양이온 라디칼의 흡광도가 항산화제에 의해 감소

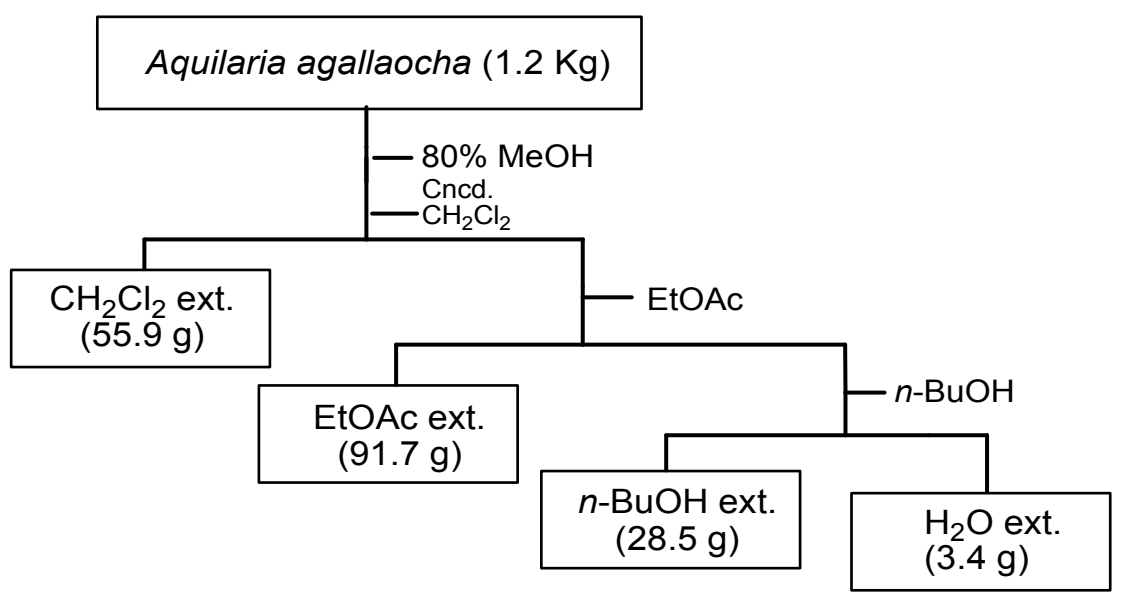

Fig. 1. Liquid-liquid partition of Aquilaria agallocha. 


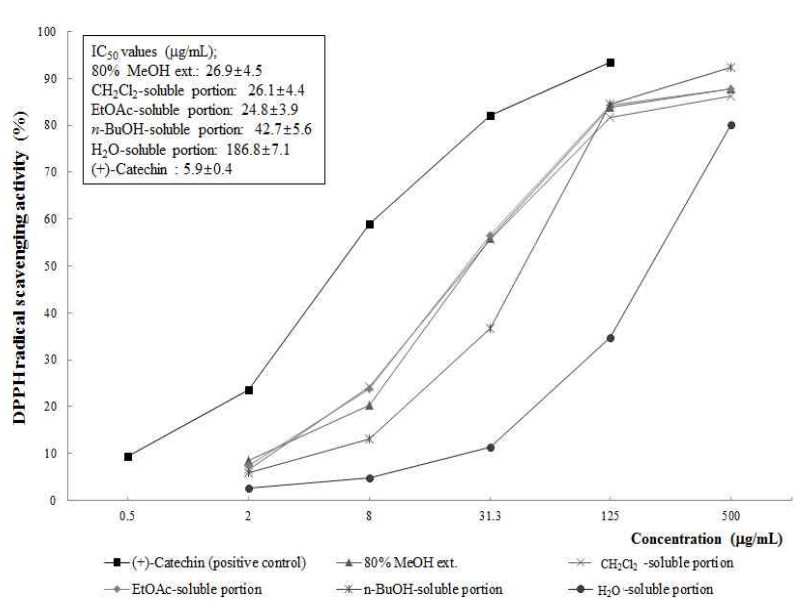

Fig. 2. DPPH radical scavenging activity of the methanolic extract of $A$ agallocha and its $\mathrm{CH}_{2} \mathrm{Cl}_{2}$, EtOAc-, $n$-BuOH-, and $\mathrm{H}_{2} \mathrm{O}$-soluble portions.

되는 원리에 기초한 방법으로, potassium persulfate와 ABTS 의 산화에 의해 라디칼을 형성시킨 후 각각의 시료에 대한 자유라디칼 소거능을 측정함으로써 항산화 활성을 확인할 수 있다. 그 결과 Fig. 3에서 보는 것처럼 침향 $80 \% \mathrm{MeOH}$ 추출물은 $14.7 \pm 0.7 \mu \mathrm{g} / \mathrm{mL}$ 에서 $\mathrm{IC}_{50}$ 값을 나나내었으며, 분 획물에 대한 라디칼 소거활성을 평가한 결과 $\mathrm{CH}_{2} \mathrm{Cl}_{2}$, $\mathrm{EtOAc}$ 및 $n \mathrm{BuOH}$ 가용부에서 각각 $5.3 \pm 0.4 \mathrm{\mu g} / \mathrm{mL}, 5.5 \pm 0.4$ $\mu \mathrm{g} / \mathrm{mL}, 10.4 \pm 0.2 \mu \mathrm{g} / \mathrm{mL}$ 의 $\mathrm{IC}_{50}$ 값을 확인하였으며, 양성 대조군인 (+)-catechin의 $\mathrm{IC}_{50}$ 값인 $2.1 \pm 0.2 \mathrm{\mu g} / \mathrm{mL}$ 과 비교시 에도 동등한 효능임을 확인하였다. 또한 Fig. 2 에서의 DPPH 라디칼 소거활성 평가 결과를 고려할 때 침향의 $80 \% \mathrm{MeOH}$ 추출물과 $\mathrm{CH}_{2} \mathrm{Cl}_{2}, \mathrm{EtOAc}$ 가용부에 우수한 항산화 활성물질 의 존재가 시사되었으며, 이들 활성물질의 동정이 필요하 다고 사료된다.

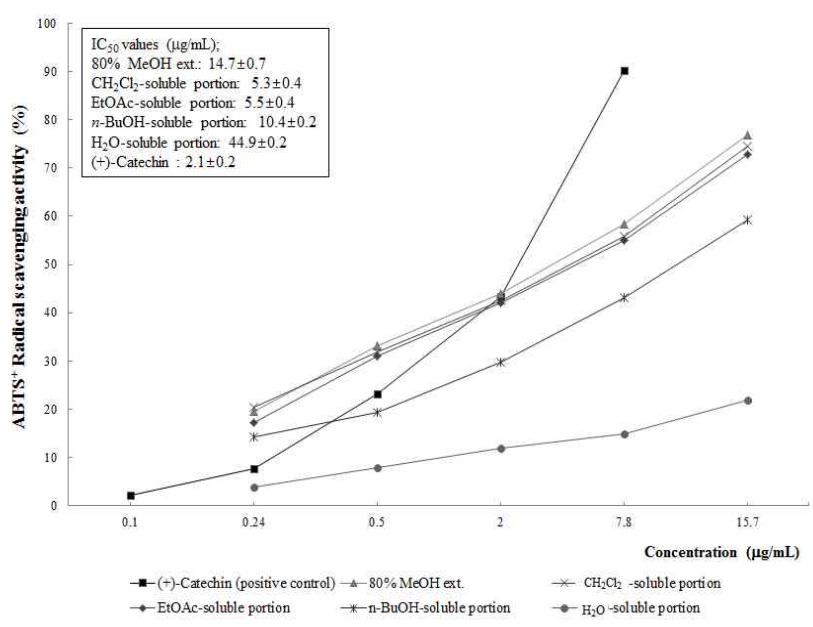

Fig. 3. ABTS+ radical scavenging activity of the methanolic extract of $A$ agallocha and its $\mathrm{CH}_{2} \mathrm{Cl}_{2}$, EtOAc-, $n$-BuOH-, and $\mathrm{H}_{2} \mathrm{O}$-soluble portions.

\section{Pancreatic lipase 저해활성}

최근 pancreatic lipase는 지방질 가수분해 효소로 지방의 소화 및 흡수에 중요한 역할을 하며 pancreatic lipase의 활성 을 억제하여 지방의 흡수를 막아 지방의 배설을 촉진하는 전략으로 많은 연구가 진행되어 지고 있다(15). 현재 시판되 고 있는 항비만 제제는 우수한 효능에 도 불구하고 우장장 애, 과민증, 담즙분비장애, 지용성비타민 흡수억제 등의 부 작용이 있는 것으로 알려져 있으며 최근에는 부작용이 없는 식품 및 천연물로부터 pancreatic lipase 저해제의 개발을 위한 연구가 진행되고 있다. 본 연구에서 항비만 소재의 개발을 위해 침향의 $80 \% \mathrm{MeOH}$ 추출물을 극성에 따라 $\mathrm{CH}_{2} \mathrm{Cl}_{2}, \mathrm{EtOAc}$ 및 $n-\mathrm{BuOH}$ 로 순차 분획하여 얻어진 각 가용 부에 대하여 pancreatic lipase를 이용한 실험을 수행하였다. 그 결과 침향의 $80 \% \mathrm{MeOH}$ 추출물의 $\mathrm{CH}_{2} \mathrm{Cl}_{2}$ 가용부에서 우수한 $1.1 \pm 0.3 \mu \mathrm{g} / \mathrm{mL}$ 의 우수한 활성을 나타내었으며, 다 음으로 $\mathrm{EtOAc}$ 가용부에서 $73.8 \pm 4.4 \mu \mathrm{g} / \mathrm{mL}, n-\mathrm{BuOH}$ 가용 부에서 $116.1 \pm 9.1 \mathrm{\mu g} / \mathrm{mL}$ 순의 $\mathrm{IC}_{50}$ 값을 확인하였다. 이상의 결과로부터 $\mathrm{CH}_{2} \mathrm{Cl}_{2}$ 가용부의 pancreatic lipase 저해활성은 positive control인 orlistat에 상당하는 항비만 활성으로 향후 활성물질 동정 및 항비만 활성메카니즘에 대한 연구가 필요 하다고 사료된다.

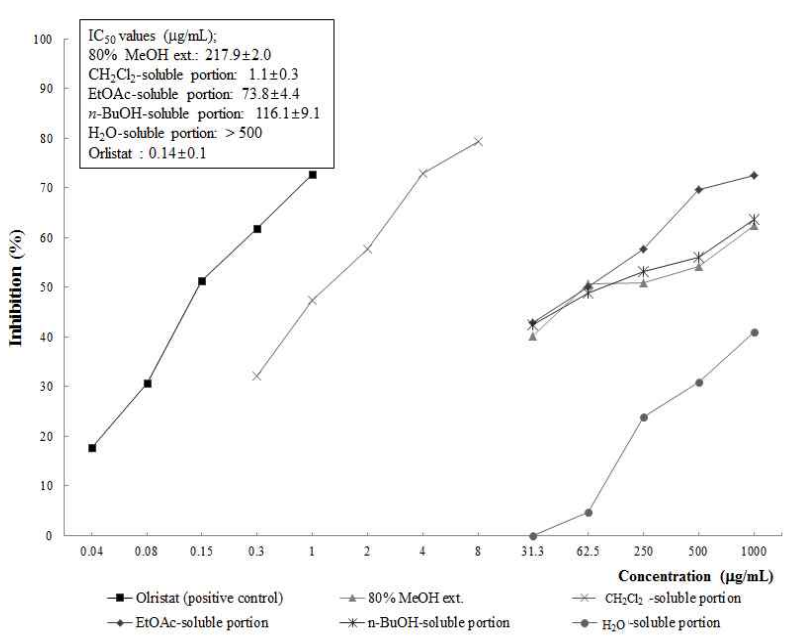

Fig. 4. Inhibitory effects of the methanolic extract of $A$ agallocha and its $\mathrm{CH}_{2} \mathrm{Cl}_{2}$, EtOAc-, $n$-BuOH-, and $\mathrm{H}_{2} \mathrm{O}$-soluble portions against pancreatic lipase.

\section{총 페놀 화합물 함량}

식물에서 항산화 활성은 주로 페닐프로파노이드, 플라보 노이드, 탄닌 등의 페놀성 화합물과과 라디칼 소거반응을 나타내며, 이러한 페놀성 화합물의 항산화활성은 자유라디 칼의 흡착과 중화 및 과산화수소의 분해 등에서 중요한 역할을 할 수 있다고 알려져 있다(35). 플라보노이드와 페놀 산은 페놀성 화합물중에 주요 타입의 화합물중 하나이며 그들의 항산화 활성은 일반적으로 하이드록실기의 개수, 
결합위치 및 당과의 결합여부와 깊은 관계가 있음이 알려져 있으며, 전통약용식물로부터 분리된 tannin, quinone, coumarin, lignan, stilbene, flavonoid 등의 천연 페놀성 화합 물에 대하여 항산화 활성을 포함한 각종 생리활성과 구조와 의 상관관계가 체계적으로 증명되어졌다(36).

침향 추출물 및 극성별 유기용매 가용부에 함유되어 있 는 페놀성 화합물의 함량을 Table 1에 나타내었으며, $\mathrm{CH}_{2} \mathrm{Cl}_{2}$ 가용부의 가용부가 $1 \mathrm{~g}$ 당 $217.2 \mathrm{mg}$ 의 가장 많은 페놀 화합물을 함유하는 것으로 나타났으며, EtOAc 가용부 에서 $211.5 \mathrm{mg} / \mathrm{g}, n-\mathrm{BuOH}$ 가용부는 $113.7 \mathrm{mg} / \mathrm{g}$ 및 $\mathrm{H}_{2} \mathrm{O}$ 가용부에서 $55.8 \mathrm{mg} / \mathrm{g}$ 의 순으로 페놀성 화합물의 함량이 감소하는 것을 확인하였다. 이상의 결과로 부터 추출물과 분획의 $\mathrm{DPPH}, \mathrm{ABTS}^{+}$양이온 라디칼 소거능을 결과를 고려 할 때, 페놀성 화합물의 함량과 라디칼 소거능 사이에는 강한 상관관계가 있는 것을 알 수 있었다.

Table 1. Total phenolic content of the methanolic extract and or ganic solvent-soluble portions of $A$ agallocha

\begin{tabular}{lc}
\hline \multicolumn{1}{c}{ Samples } & Phenolic contents $(\mathrm{mg} / \mathrm{g})^{1)}$ \\
\hline $80 \% \mathrm{MeOH}$ ext. & $217.2 \pm 5.1$ \\
$\mathrm{CH}_{2} \mathrm{Cl}_{2}$-soluble portion & $339.7 \pm 3.7$ \\
EtOAc-soluble portion & $211.5 \pm 2.0$ \\
$n$-BuOH-soluble portion & $113.7 \pm 2.7$ \\
$\mathrm{H}_{2} \mathrm{O}$ residue & $55.8 \pm 1.2^{\star}$ \\
\hline
\end{tabular}

${ }^{1)}$ Data represent the mean \pm SD three replications and ${ }^{*} \mathrm{p}<0.01$ compared with control.

\section{요 약}

팥꽃나무과 방향성 수지질의 상록성 교목인 침향을 $80 \%$ $\mathrm{MeOH}$ 로 침지 추출하여 얻어진 추출물에 대해 $\mathrm{CH}_{2} \mathrm{Cl}_{2}$, $\mathrm{EtOAc}$ 및 $n \mathrm{BuOH}$ 로 순차 용매 분획하였고, 얻어진 결과물 에 대하여 녹차의 항산화 성분으로서도 잘 알려져 있는 천연 항산화제인 (+)-catechin을 대조군으로 하여 $\mathrm{DPPH}$, $\mathrm{ABTS}^{+}$라디칼 소거법에 의한 항산화활성 평가를 실시한 결과, 항산화 활성은 시료의 처리농도에 비례하게 효능을 나타내는 것으로 확인되었으며 그중에서도 DPPH 라디칼 소거활성은 페놀성 화합물의 함량이 상대적으로 높은 $\mathrm{CH}_{2} \mathrm{Cl}_{2}$ 가용부에서 $26.1 \pm 4.4 \mu \mathrm{g} / \mathrm{mL}, \mathrm{EtOAc}$ 가용부에서 $24.8 \pm 3.9 \mu \mathrm{g} / \mathrm{mL}$ 의 우수한 $\mathrm{IC}_{50}$ 값을 나타내었다. 또한 $\mathrm{ABTS}+$ 라디칼 소거능은 $\mathrm{CH}_{2} \mathrm{Cl}_{2}, \mathrm{EtOAc}$ 및 $n \mathrm{BuOH}$ 가용부 에서 각각 $5.3 \pm 0.4 \mu \mathrm{g} / \mathrm{mL}, 5.5 \pm 0.4 \mu \mathrm{g} / \mathrm{mL}$ 활성이 확인 되었 으며, 총 페놀함량과의 강한 상관관계가 시사되었고 페놀 성의 활성물질의 존재가 시사되었다. 또한, 항비만 활성과 관련된 pancreatic lipase 저해활성을 측정한 결과, 오일의 형태로 얻어진 $\mathrm{CH}_{2} \mathrm{Cl}_{2}$ 가용부의 $\mathrm{IC}_{50}$ 값은 $1.1 \pm 0.3 \mu \mathrm{g} / \mathrm{mL}$ 의 저해율을 나타내었으며 이는 대조군인 orlistat에 비해 약하
나 추출물 상태임을 고려할 때 단일물질로 정제할 경우 더욱 우수한 효능의 화합물이 존재할 가능성을 시사하였 다. 향후 이들 식의약품 소재개발을 위한 구체적인 자료 수립을 위하여 효소활성을 나타내는 성분들에 대해 활성추 적탐색법(activity-guided isolation)에 따라 활성물질을 추 적, 분리하는 연구를 통한 효능물질의 동정 및 활성 기작에 대한 연구가 필요하며, 침향의 식물 화학적 성분연구에 대 한 기초자료로 활용가능하리라 사료된다.

\section{감사의 글}

본 연구는 한국연구재단 기초연구사업 지원에 의해 수행 된 연구과제(2010-0022783)결과의 일부로서 이에 감사드 립니다.

\section{References}

1. Videla LA, Fermandez V (1988) Biochemical aspects of cellular oxidative stress. Arch Biol Med Exp, 21, 85-92

2. Halliwell B, Aruoma OJ (1991) DNA damage by oxygen-derived species. FEBS Lett, 281, 9-19

3. Jennings PE, Barnett AH (1988) New approaches to the pathogenesis and treatment of diabetic microangiopathy, Diabetic Med, 5, 111-117

4. Shim JS, Kim SD, Kim TS, Kim KN (2005) Biological activities of flavonoid glycosides isolated from Angelica keiskei. Korean J Food Sci Technol, 37, 78-83

5. Farag RS, Badei AZMA, Hewedi FM, El-Baroty GSA, (1989) Antioxidant activity of some spice essential oils on linoleic acid oxidation in aqueous media. J American Oil Chem Soc, 66, 792-799

6. Frei B (1994) National antioxidants in human health and disease, Academic Press, San Diego, p 44-55

7. Branen AL (1975) Toxicology and biochemistry of butylated hydroxy anisole and bytylated hydoxytoluane. J Oil Chem Soc, 52, 59-62

8. Masaki H, Sakaki S, Atsumi T, Sakurai H (1995) Active-oxygen scavenging activity of plants extracts. Biol Pharm Bull, 18, 162-166

9. Bray GA, Popkin BM (1998) Dietary fat intake dose affect obesity. Am J Clin Nutr, 68, 1157-1173

10. Bray GA, Popkin BM (1999) Dietary fat affects obesity rate. Am J Clin Nutr, 70, 572-573

11. Levinson ML (1977) Obesity and health. Prev Med, 6, 172-180 
12. Rexrode KM, Manson JE, Hennekens CH (1996) Obesity and cardiovascular disease. Curr Opin Cardiol, 11, 490-495

13. Sjostrom L (1992) Morbidity of severely obese subjects. Am J Cliv Nutr, 55, 508-515

14. Bitou N, Nimomiya M, Tsjita T, Okuda H (1999) Screening of lipase inhibitors from marine algae. Lipids, $34,441-445$

15. Drent ML, Larsson I, William-Olsson T, Quaade F, Czubayko F, Von Bergmann K, Strobel W, Sjotro L, Van der Veen EA (1995) Orlistat (RO 18-0647), a lipase inhibitor, in the treatment of human obesity : a multiple dose study. Int J Obesity, 19, 221-226

16. Hadvay P, Lengsfeld H, Wolter H (1988) Inhibition of pancreatic lipase in vitro by covalent inhibitor tetrahydrolipstatin. Biochem J, 256, 357-361

17. Peter C, Williams G (2001) Drug treatment of obesity : from past failures to future successes?. $\mathrm{Br} \mathrm{J}$ Clin Pharmacol, 51, 135-141

18. Yamamoto M, Shimura S, Itoh Y, Ohsaka T, Egawa M, Inoue $S$ (2000) Anti-obesity effects of lipase inhibitor CT-II, an extract from edible herbs, Nomame Herba, on rats fed a high-fat diet. Int J Obesity, 24, 758-764

19. Kim HY, Kang MH (2005) Screening of Korean medicinal plants for lipase inhibitory activity. Phytother Res, 19, 359-361

20. Lee EM, Lee SS, Chung BY, Cho JY, Lee IC, Ahn SR, Jang SJ, Kim TH (2010) Pancreatic lipase inhibition by C-glucosidic flavones isolated from Eremochloa ophiuroides. Molecules, 15, 8251-8259

21. Hong JY, Shin SR, Bae MJ, Bae JS, Lee IC, Kwon OJ, Jung JW, Kim YH, Kim TH (2010) Pancreatic lipase inhibitors isolated from the leaves of cultivated mountain ginseng (Panax ginseng). Korean J Food Preserv, 17, 727-732

22. Park CH, Chung BY, Lee SS, Bai HW, Cho JY, Jo C, Kim TH (2013) Radiolytic transformation of rotenone with potential anti-adipogenic activity. Bioorg Med Chem Lett, 23, 1099-1103

23. Yuk CS, Lee SW, Yu SJ, Kim TH, Hahn YK, Lee SY, Moon YH, Hahn MW, Lee, KS (1981) Herbal Medicine of Korea, Gyechukmunwhasa, Seoul, p 345

24. Kim YC, Lee EH, Lee YM, Kim KH, Song B, Lee EJ,
Kim HM (1997) Effect of the aqueous extract of Aquilaria agallocha stems on the immediate hypersensitivity reactions. J Ethnopharmacol, 58, 31-38

25. Dash M, Patra JK, Panda PP (2008) Phytochemical and antimicrobial screening of extracts of Aquilaria agallocha Roxb. Afr J Biotech, 7, 3531-3534

26. Miniyar BP, Chitre TS, Karve SS, Deuskar HJ, Jain KS (2008) Antioxidant activity of ethylacetate extract of Aquilaria agellocha on nitrite-induced methemoglobin formation. Int J Green Pharm, 1, 43-44

27. Konishi T, Sugimoto A, Kiyosawa S, Fujiwara Y (1992) Studies on Agarwood (jinko).XII Structures of pentahydroxy-2-(2-phenethyl) chromone derivative. Chem Pharm Bull, 40, 778-779

28. Ishihara M, Tsuneya T, Uneyama K (1993) Sesquiterpene constituents in agarwood, Phytochem, 33, 1147-1155

29. Bhandari P, Pant P, Restogi RP (1982) Aquillochin, a coumarinolignan from Aguilaria gallocha, Phytochem, 21, 2147-2149

30. Blois MS (1958) Antioxidant activity determination by the use of a stable free radical. Nature, 181, 1199-1200

31. Re R, Pellegrini N, Proteggente A, Pannala A, Yang M, Rice-Evans C (1999) Antioxidant activity applying and improved ABTS radical cation decolorization assay. Free Radic Biol Med, 26, 1231-1237

32. Kim JH, Kim HJ, Park HW, Youn SH, Choi DY, Shin CS (2007) Development of inhibitors against lipase and alpha-glucosidase from derivatives of monascus pigment. FEMS Microbiol Lett, 276, 93-98

33. Singleton V, Orthofer R, Lamuela-Raventos RM (1999) Analysis of total phenols and other oxidation substrates and antioxidants by means of Folin-Ciocalteu reagent. Methods Enzymol, 299, 152-172

34. Torel J, Gillard J, Gillard P (1986) Antioxidant activity of flavonoids and reactivity with peroxy radical. Phytochem, 25, 383-385

35. Cao G, Sofic E, Prior R (1997) Antioxidant and prooxidant behavior of flavonoids: structure-activity relationships. Free Radic Biol Med, 22, 749-760

36. Cai YZ, Mei S, Xing J, Luo Q, Corke H (2006) Structure-radical scavenging activity relationships of phenolic compounds from traditional Chinese medicinal plants. Life Sci, 15, 2872-2888 